\title{
Development of a Strategic Management System Based on Realizing the Potential of Integrated Entity
}

\author{
Gubaidullina T.N. \\ Kazan Federal University, Institute of Management, Economics and Finance, Kazan, 420008, Russia \\ Nugumanova L.F. \\ Kazan Federal University, Institute of Management, Economics and Finance, Kazan, 420008, Russia \\ Antonova N.V. \\ Kazan Federal University, Institute of Language, 420008, Kazan, Russia
}

\section{Doi:10.5901/mjss.2015.v6n3p746}

\begin{abstract}
The article proves that to implement a social-oriented regional development model it is necessary to apply the key competences concept for the system of cluster strategic management in real economy. The cluster performance system for consumer goods industry is updated by including social efficiency index in investment projects alongside technical-andeconomic ones. The article also provides an analysis of public and private partnership forms involving consumer industry clusters and reveals the way cluster development level influences the regional development social indexes.
\end{abstract}

Keywords: regional economy, clusters, investment projects, public and private partnership, regional development social indexes.

\section{Introduction}

In the age of controversial globalization and regionalization trends whole new phenomena appear in the world economy, which modify and complicate form and content of industrialization processes as a strategic economy sector. They have an immediate effect on strategic aims and priorities of social and economic development of the state and its sub-national entities. This necessitates creation and implementation of a national economic system, cross-industry networks, individual production brunches and industries.

Influential contribution to the contemporary system of regional economic development trends was made by such scholars as Johann Heinrich von Thünen (model of agricultural land), Carl Wilhelm Friedrich Launhardt (theory of the Location of Industries), Alfred Weber (theory of location of inductries), A. Predel and T.F. Palander (modern location theory), August Lösch (spatial organization of the economy), R. Groce (optimization of multi-factory businesses location), Harold Hotelling (conception of "spatial economics"), Raymond Vernon (product life-cycle theory) and others [2, 3, 4, 5, 6, 9 , 11]. Theoretical approaches to implementing cluster strategies are presented in the works by M. Lorencen, P. Maskell, M. Porter, R. Rosenfeld, M. Storper, M. Enright, etc. $[1,7,10]$.

The current ambiguous attitude to the problem of cluster creation among Russian scholars requires an in-depth study of the possibility to create whole new integrated structures, aimed to realize their members' innovation and investment potential, as well as analyze the mechanisms of regional control over consumer industry clusters, their role in enhancing social-oriented state economic policy. These facts have set the research agenda and structure for the given study.

\section{Methods}

A comparative analysis of clusters which develop around the central enterprises and conduct various economic activities, allows us to infer that the sets of their key competences do not coincide. Clusters which emerged in consumer industry can be distinguished by the following characteristics:

- industrial, marketing, labor, managerial, investment and social core competences, the letter playing the key 
role in terms of the product's value to the customer (the majority of consumer goods are primary commodities);

- differentiation business strategy (development of unique skills and abilities, which permits employing people with limited capability for work along with high share of female population; gives an opportunity to distribute hands geographically and use work from home, as well as create a powerful incentive programme);

- final goods market diversification (ability to surpass the competitors strategically, strategic flexibility and high adaptation rate, end market expansion capacity, high business logistics level).

The suggested method to create and develop core competences in consumer industry allows the problem of core competences management to be solved at each separate stage of design and implementation of the cluster strategy.

\section{Results}

The analysis of employment patterns in Volga Region federal district reveals that economic activity among males is considerably higher than among females (72.6 and 60.4 correspondingly). To estimate gender composition at the sectoral level it is necessary to calculate the gender index of labor potential analysis or gender composition index for one male labourer:

$$
\Gamma K_{m n}=\frac{C_{\varkappa-}-\left(\left(O_{\tilde{\sigma} p}+O_{y x}\right) \times K_{\phi}\right)-\overline{5}}{C M}
$$

Where

ГКтп - is the gender index of labor potential analysis,

Сж - is the maximum possible total length of service for women (16-55 years of age) in days,

Oбp - duration of maternity leave,

Oyx - duration of child-care leave (up to the age of three years) in days,

Kф - fertility index,

$\mathrm{E}$ - average care-giving leave duration (in days) to attend to a child up to 14 years of age,

См - is the maximum possible total length of service for men (16-60 years of age).

To estimate the efficiency of using female labor potential in a certain region or economic sector, considering actual balance between male and female employees the formula should be modified in the following fashion:

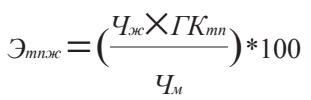

Where

Этпж - is female labor force efficiency,

Чж - number of female employees (in economy, sector or industry)

Чм - number o male employees.

Gender index to assess labor force acts as an adjustment (correcting) factor in this formula, i.e. it lowers the female labor force index, taking into account fertility function.

In the Republic of Bashkortostan (RB) consumer industry the share of females among economically inactive population increased by $11 \%$ over a period between 2002 and 2010, which led to the growth of gender ratio among economically active population. The current trend can be treated in different ways. Firstly, the increase in gender disproportion stems from rising of living standards, including considerable salary increase in "male" industrial sectors, such as petroleum processing and long-distance transportation (oil-pipe lines, road haulage, etc.). this trend reestablishes the traditional gender roles. Secondly, salary increase in "male" industrial sectors increases gender disproportion in salaries and emoluments, which may be regarded as a financial expression for gender ratio ("income effect" and "substitution effect"). Thirdly, male to female ratio growth is conditioned by labor market immaturity. For instance, family domestic obligations do not allow female workers to work on a full time basis or outside the home, but leave certain amount of spare time to realize their personal potential in the labor sphere. However, because of the labor market immaturity, it is quite difficult for females to enter it. Fourthly, male to female ratio growth is related to the structure of labor market.

Therefore, bt introducing the concept of core competences into the system of cluster strategic management and implementing social core competence we can lower gender disparity index due to change in the labor market structure. Implementation of cluster core competences implies active state supervision, which consists in allocating funds from the regional budget within the framework of public private partnership in order to:

- provide advance occupational training for women,

- pay partial compensation to businesses for covering the expenditures for creating special jobs for people with 
disabilities and giving them payment, including work from home;

- support self-employment and encourage those unemployed citizens who set up their own business to create additional jobs.

Work cycle features of the economic sector presuppose a possibility of extensive use of job dispersion over space. Cluster network structure and its use for information and communication technologies enhance the process.

The performance index for the cluster social core competence is an increase in gender economic culture on the territory where the cluster is located, including:

- equalizing payment between economic sectors and lowering the disparity between type of work and payment for men and women, adhering to the requirements of equal payment for similar work;

- increasing employment level based on the gender equality principle;

- lowering unemployment level and scale aiming to root out such a phenomena as local or mass joblessness, generally characterized by gender discrimination;

- improving working conditions with due regard to gender equality and applying flexible approach to liberating women from heavy work and harmful or hazardous labor conditions;

- design and implementation of regional government programmes to support small businesses, specifying the measures to promote female and family business and organize business incubators;

- improvement of consulting and credit offices for small and medium businesses, as well as targeted support for businesswomen;

- creating conditions for labor activity and successful career for people with family obligations, taking measures to protect maternity and enhance equality between men and women.

In the course of the study, a method to conduct a comparative analysis into fulfillment of core competences by consumer industry cluster performance has been suggested and approved (table 1).

Table 1. Key cluster performance indicators for consumer industry in Russian regions

\begin{tabular}{|c|c|c|c|}
\hline \multirow[b]{2}{*}{ Key indicators } & \multicolumn{3}{|c|}{ Cluster } \\
\hline & 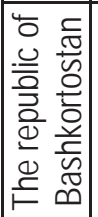 & 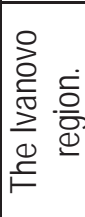 & 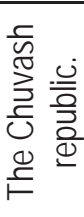 \\
\hline Cluster's share in the total stock of fixed assets in the sector, $\%$ & 3 & 1 & 0,2 \\
\hline Cluster's share in the sector gross output, $\%$ & 2,2 & 0,9 & 0,1 \\
\hline Cluster's share in the total number of industries in the sector, $\%$ & 2 & 0,5 & 0,1 \\
\hline $\begin{array}{l}\text { Equity contribution to the cluster's capital stock against the overall investment volume in the } \\
\text { sector, \% }\end{array}$ & 6 & 2 & 1 \\
\hline Cluster's share in total employment volume in the sector, \% & 4 & 2 & 0,4 \\
\hline Cluster mission effectiveness & 5 & 3 & 1 \\
\hline Cluster financial effectiveness & 6 & 4 & 2 \\
\hline Cluster integrate macroeconomic effectiveness & 5 & 3 & 1 \\
\hline Cluster equilibrium effectiveness & 12 & 8 & 2 \\
\hline Cluster dynamic effectiveness (sector product output growth rate) & 8 & 7 & 2 \\
\hline $\begin{array}{l}\text { Money turnover ratio efficiency in the national budget and the cluster (estimating national } \\
\text { budget financial costs to support the cluster) }\end{array}$ & 6 & 4 & 1 \\
\hline Cluster competitive (price) efficiency (relative mark-up index) & 4 & 2 & 1 \\
\hline Time parameters of the economic cycle (weeks) & 4 & 2 & 2 \\
\hline Market share in the business segment where it operates, $\%$ & 23 & 31 & 9 \\
\hline Production profitability, $\%$ & 25 & 18 & 13 \\
\hline Innovation (number of innovative projects and inventions implemented in a year) & 77 & 16 & 4 \\
\hline Staff turnover & 6 & 2 & 12 \\
\hline Cluster social efficiency & 5 & 3 & 2 \\
\hline
\end{tabular}


Apart from traditional indexes the suggested system includes cluster social efficiency index, which is defined through expert estimation by the following criteria:

- ability to secure salary payment in an amount no lower than double relative to the minimum subsistence income for the RB territory;

- a complex of tax and non-tax payments into the budgets of all levels and non-budgetary foundations, social benefits and businesses' social expenditures per worker no less than double relative to the size of budget costs of state public services corresponding to one RB citizen;

- job formation;

- existence and completeness of social reporting;

- participation in public and private partnership projects;

- conformance of economic sector business activity to environmental standards and image making strategy of the region.

It is also desirable for cluster businesses to provide both budget efficiency and social efficiency assessments while implementing investment projects. Budget efficiency assessment is defined as a difference between the regional budget income from implementing the investment project over the breakeven years and the amount of appropriation from the local budget to implement the project.

The analysis into cluster development trends, social competence being the key competence in their strategic plans, and their impact on the most essential social indicators has revealed several points. Positive progressive advance in social-oriented clusters has an immediate effect on consumer confidence index for those individuals whose income is lower than average, as well as a strong reverse effect - the proportion of the population whose income is lower than minimum subsistence level and average monthly payment (correlation indexes calculated on the basis of retrospective data for the republic of Bashkortostan, are as follows: $+0,9703,-0,9553$ and $-0,7634)$. Therefore, efficient regional cluster development management based on social competence will make it possible to reduce the ratio of population with salaries lower than minimum subsistence income (by releasing them from state social responsiveness sphere and giving an opportunity of self employment without withdrawing from them social benefits and protection) and thus increase the consumer confidence index for this population category. The forecasting of development for the Bashkortostan republic was conducted according to the parameters for the group of population whose income is lower than subsistence income and consumer confidence index of this social group. It is based on linear regression equations created in accordance with the data on the region's development by the following scenarios:

1. Scenario A presupposes lower growth rate of social-oriented regional clusters against the current trends.

2. Scenario $B$ implies maintaining the existing growth rate of social-oriented regional clusters.

3. Scenario $\mathrm{C}$ implies social-oriented regional clusters' increasing growth rate against the current trends.

The results of the forecasting are presented in figure 1.

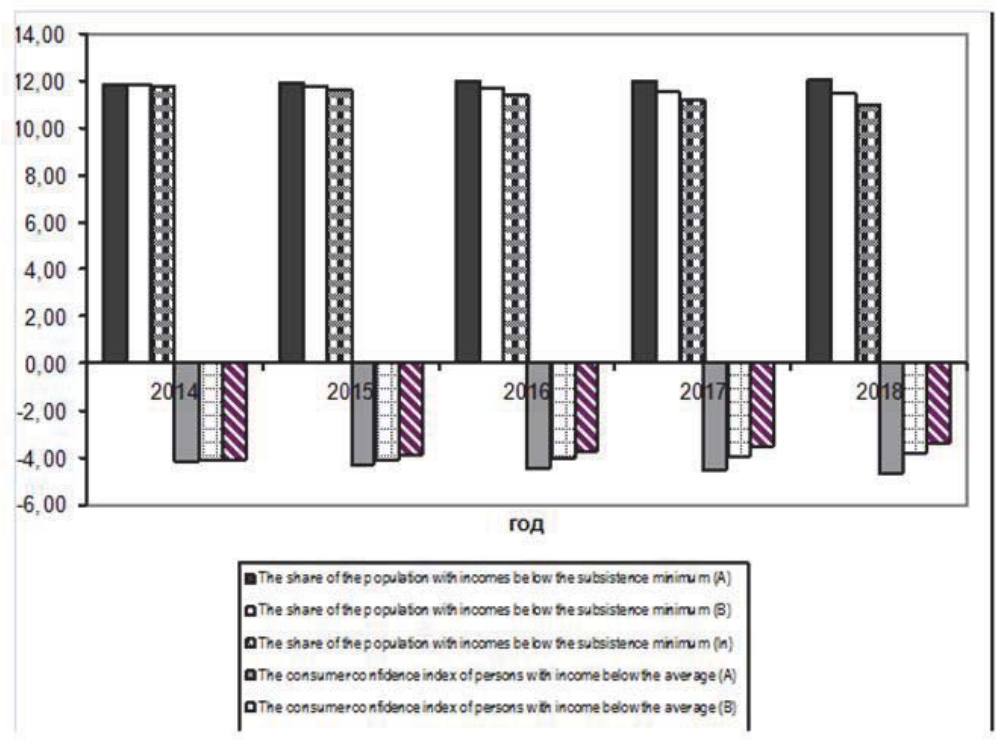

Figure 1. Trends in share of population with the income lower than subsistence level and consumer confidence index for the given population category for 2014-2018 (forecast) 


\section{Conclusions}

The present data indicate that cluster development with social competences will make it possible to provide stable improvement of region's social indexes even under unfavorable circumstances in the external environment.

Therefore, by implementing the above mentioned measures we can provide sustainable development of sub-national entities as well as raise living standards and quality.

\section{References}

Bagautdinova N.G., Gafurov I.R., Novenkova A.Z. The transformation of region's economic area governed by the development of industrial region // World Applied Sciences Journal, 25(7), 2013, 1113-1117.

Bagautdinova, N.G., Panasyuk, M.V., Gafurov, I.R. Wavelet analysis of the territorial socio-economic system dynamics // World Applied Sciences Journal, 27(13), 2013, 62-66.

Lundvall B.A. The Learning Economy - Challenges to Economic Perspectives on Markets, Frims and Technology / Edited by B.Johnson, K.Nielsen. I.: Edward Elgar, 1998. - pp. 33-54.

Askhatova L.I., Fatkhiev A.M., Safiullin L.N. and Safiullina A.M. Competitive Strategies Formation in High Technology Enterprise // World Applied Sciences Journal, 27(13), 2013, pp. 20-23.

Malizia, Emil E. and Edward J. Feser.. Understanding Local Economic Development. New Brunswick, NJ: Center for Urban Policy Research, Rutgers University, 1999.

Maskell P., Larenzen M. The Claster as Market Organizantion. DRUID Working Paper 03-14, 2003. - 29 p.

Porter M. The Competitive Advantage of Nations: With a New Introduction. N.Y.: The Free Press, Palgrave Tenth Edition, 1998. - 855p.

Regional Clusters in Europe. Observatory of European SMEs, № 3, 2002. Luxembourg: Office Publications of the European Communities, 2002. - 66p.

Rosenfeld S.A. Bringing Business Clusters into the Mainstream of Economic Development // European Planning Studies, Nr. 5, 1997. pp. 3-23.

Askhatova L.I., Bulnina I.S. Quality-of-life (QOL) improvement as a strategic resource of sustainable social and economic development of a region. Life Science Journal $2014 ; 11(6 \mathrm{~s}): 354-357$.

Enright M. The Geographical Scope of Competitive Advantage // Stuck in the Region? Changing scales for regional identity / Ed by E. Dirven, J. Grocnewegen and S/ van Hoof.Utrecht, 1993. P.87-102

Sarkin, A.V., Bagautdinova, N.G., Averianov, B.A. Formulation of development strategies of machinery building complex enterprises and estimation of their implementation efficiency // World Applied Sciences Journal, 27(13), 2013, 170-173.

Storper M. The Regional World: Territorial Development in Global Economy. N.Y.; Guilford Press, 1997. - 338 p. 